\title{
Construction of a Novel Bifunctional Biogenic Amine Receptor by Two Point Mutations of the H2-Histamine Receptor
}

\author{
John DelValle,* Ira Gantz, ${ }^{\dagger}$ Lidong Wang,* Yi-Jun Guo,* \\ Gerd Munzert,* Takao Tashiro,* Yoshitaka Konda,* \\ and Tadataka Yamada** \\ Departments of *Internal Medicine, ' ${ }^{\dagger}$ urgery, and ${ }^{\ddagger}$ Physiology, \\ University of Michigan Medical Center, Ann Arbor, Michigan, U.S.A.
}

\begin{abstract}
Background: H2-histamine receptors mediate a wide range of physiological functions extending from stimulation of gastric acid secretion to induction of human promyelocyte differentiation. We have previously cloned the H2-histamine receptor gene and noted that only three amino acids on the receptor were sufficient to define its specificity and selectivity. Despite only modest overall amino acid homology $(34 \%$ amino acid identity and $57.5 \%$ similarity) between the $\mathrm{H} 2$-histamine receptor and the receptor for another monoamine, the $\beta 2$ adrenergic receptor, there is remarkable similarity at their critical ligand binding sites. We hypothesized that, if the specificity and selectivity of both receptors are invested in just three amino acids, it should be possible to convert one of the receptors into one that recognizes the ligand of the other by simple mutations at only one or two sites.

Material and Methods: We explored the effect of two single mutations in the fifth transmembrane domain of the $\mathrm{H} 2$-histamine receptor, which encompasses the sites that determine $\mathrm{H} 2$ selectivity. The canine $\mathrm{H} 2$ receptor gene was mutated at $\mathrm{Asp}^{186}$ and $\mathrm{Gly}^{187}$ (Asp $^{186}$ to $\mathrm{Ala}^{186}$ and $\mathrm{Gly}^{187}$ to $\mathrm{Ser}^{187}$ ) by oligonuceotide directed $\mathrm{mu}$ tagenesis. The coding region of both the wild-type and mutated $\mathrm{H} 2$ receptors was subcloned into the eukaryotic
\end{abstract}

expression vector, CMVneo, and stably transfected into Hepa cells and L cells. The biological activity of histamine and epinephrine on the expressed receptor was examined by measurement of cellular cAMP production and inositol trisphosphate formation.

Results: Hepa cells transfected with the $\mathrm{Ala}^{186}-\mathrm{Ser}^{187}$ mutant $\mathrm{H} 2$ receptor demonstrated a biphasic rise in cAMP in response to epinephrine with an early phase $\left(\mathrm{ED}_{50} \approx 10^{-11} \mathrm{M}\right)$ that could be inhibited by both propranolol and cimetidine. Epinephrine also induced IP3 generation in the same cells, a biological response that is characteristic of activation of the wild-type $\mathrm{H} 2$ but not of the $\beta$-adrenergic receptor. $L$ cells transfected with the $\mathrm{Ala}^{186}$-Ser ${ }^{187}$ mutant $\mathrm{H} 2$ receptor also responded to epinephrine in a cimetidine and propranolol inhibitable manner.

Conclusions: We converted the H2-histamine receptor into a bifunctional one that has characteristics of both histamine and adrenergic receptors by two simple mutations. These results support the hypothesis that ligand specificity is determined by only a few key points on a receptor regardless of the structure of the remainder of the molecule. Our studies have important implications on the design of pharmacological agents targeted for action at physiological receptors.

\section{INTRODUCTION}

The availability of genes encoding an increasingly wide array of receptors for regulatory substances has led to insight into the molecular basis of ligand-receptor interactions. Recently, we

Address correspondence and reprint requests to: John DelValle, 6520 MSRBI, Ann Arbor, MI 48109-0682. cloned the H2-histamine receptor gene (1) and noted that only three amino acids on the receptor were sufficient to define the specificity and selectivity of the receptor (2). By extrapolation of these findings, it is conceivable that ligand specificity is determined by only a few key points on a receptor regardless of the structure of the remainder of the molecule. We have previously 


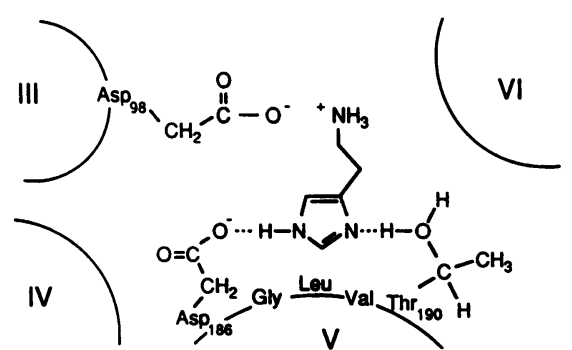

FIG. 1. Schematic drawing of the interaction of histamine with the H2-histamine receptor

The amino acid sequences of the homologous regions of the $\mathrm{H} 2$-histamine and $\beta 2$-adrenergic receptors (amino acids 186-190 and 203-207 on the respective receptors) are indicated below. The two alterations made in the mutant receptor are indicated with italics. (From Ref. 2.)

noted a remarkable similarity between the $\mathrm{H} 2$ histamine receptor and the receptor for another monamine, the $\beta 2$-adrenergic receptor, at their critical ligand binding sites. However, there is otherwise only modest overall amino acid homology (34\% amino identity and $57.5 \%$ similarity), and, furthermore, there is no evidence to indicate cross-reactivity of histamine at $\beta 2$-adrenergic receptors or, conversely, catecholamines at $\mathrm{H} 2$-histamine receptors. We reasoned that, if our hypothesis that the specificity and selectivity of both receptors are invested in just three amino acids is correct, it should be possible to convert one of the receptors into one that recognizes the ligand of the other by simple mutations at only one or two sites. In the present studies, we provide support for this hypothesis by demonstrating that two amino acid substitutions are sufficient to convert the H2-histamine receptor into a novel bifunctional receptor that has characteristics of both histamine and adrenergic receptors.

For these studies, we took advantage of the fact that key areas of homology between the $\mathrm{H} 2$-histamine and $\beta 2$-adrenergic receptors suggest specific amino acids in the third and fifth transmembrane domains of the receptors that might be important for ligand recognition and binding (Fig. 1). Both receptors contain an aspartic acid in the third transmembrane domain that serves as a counter anion to the cationic amine moiety of histamine and catecholamines $(2,3)$. In the fifth transmembrane domain, $\beta 2$-adrenergic receptors contain two serine moieties $\left(\mathrm{Ser}^{204}\right.$ and $\mathrm{Ser}^{207}$ ) that are thought to serve as points for hydrogen bonding to the hydroxyl groups in the catechol ring (4). The H2-histamine receptor has aspartic acid and threonine residues in a comparable but not identical region of its fifth transmembrane domain $\left(\mathrm{Asp}^{186}-\mathrm{Thr}^{190}\right)$ that are important for binding to the imidazole ring of histamine (2). Thus, there is remarkable similarity in the ligand binding sites for histamine and catecholamines on the $\mathrm{H} 2$-histamine and $\beta 2$-adrenergic receptors, respectively, despite the relative lack of homology in the rest of their structure. In light of this observation, we explored the effect of two simple mutations (Asp ${ }^{186}$ to $\mathrm{Ala}^{186}$ and $\mathrm{Gly}^{187}$ to $\mathrm{Ser}^{187}$ ) on the pharmacological characteristic of the H2-histamine receptor. We reasoned that these amino acid substitutions, designed to make the putative ligand binding site of the $\mathrm{H} 2$-histamine receptor resemble more closely that of the $\beta 2$-adrenergic receptor, would convert the $\mathrm{H} 2$-histamine receptor into one that recognizes catecholamines.

\section{METHODS}

\section{Mutagenesis and Expression}

For our studies, the canine H2-histamine receptor gene was subcloned into the sequencing vector M13 and used as a template for the synthesis of DNA with specific mutations according to the method of Kunkel (5). A polymerase chain reaction (PCR) strategy was used to subclone the coding region of both the wild-type and mutated H2-histamine receptors into the eukaryotic expression vector CMVneo, as previously described $(2,6)$. Hepa cells (derived from a rat hepatoma) and $\mathrm{L}$ cells (derived from a mouse fibroblast-like cell) were then transfected with the receptor/ CMVneo constructs by calcium phosphate coprecipitation (7) and clones were selected in media containing the neomycin analogue G-418. The expression of receptor RNA was examined by Northern blot analysis and clones expressing roughly equivalent amounts of receptor RNA were used for further studies.

\section{CAMP Assays}

Intracellular cyclic 3', 5'-adenosine monophosphate (cAMP) accumulation was measured using a cAMP Assay Kit (TRK 432; Amersham, Arlington Heights, IL, U.S.A.). Cells transfected with the receptor genes were grown to confluence in 12-well $(2.4 \times 1.7 \mathrm{~cm})$ tissue culture plates. The cells were maintained in Dulbecco's modified 
Eagle's medium (DMEM; Gibco, Grand Island, $\mathrm{NY}$ ) containing $4.5 \mathrm{~g} / 100 \mathrm{ml}$ glucose, $10 \%$ fetal calf serum, 100 units/ml penicillin and streptomycin, $1 \mathrm{mM}$ sodium pyruvate and $1 \mathrm{mg} / \mathrm{ml}$ of geneticin. For assays, this media was removed and cells were washed twice with Earle's balanced salt solution (EBSS) containing $10 \mathrm{mM}$ HEPES ( $\mathrm{pH} 7.4$ ), $1 \mathrm{mM}$ glutamine, $26.5 \mathrm{mM}$ sodium bicarbonate, and $100 \mathrm{mg} / \mathrm{ml}$ bovine serum albumin. An aliquot $(0.5 \mathrm{ml})$ of EBSS was placed into each well along with $5 \mu \mathrm{l}$ of $2 \times 10^{-2}$ $M$ isobutylmethylxanthine. Varying concentrations of agonist were added and the cells were incubated for $30 \mathrm{~min}$ at $37^{\circ} \mathrm{C}$. Ice-cold $30 \%$ trichloracetic acid $(500 \mu \mathrm{l} /$ well $)$ was added to stop the reaction and precipitate cellular protein. The cells were scraped and transferred to $16 \times 150$ $\mathrm{mm}$ glass tubes then placed on ice for $30 \mathrm{~min}$. The precipitate was then centrifuged for $10 \mathrm{~min}$ at $1,900 \times \mathrm{g}$ and the supernatant was ether extracted, lyophilized, and resuspended in 50 $\mathrm{mM}$ tris, 2 mM EDTA (pH 7.5). cAMP content was then measured by competitive binding assay according to the assay instructions.

\section{Inositol Phospholipid Assays}

Transfected Hepa cells were grown to confluence in $2.4 \times 1.7 \mathrm{~cm}$ multiwell plates and prelabeled with myo $\left[2-^{3} \mathrm{H}\right]$ inositol at $37^{\circ} \mathrm{C}$ for $2 \mathrm{hr}$, adding $\mathrm{LiCl}(10 \mu \mathrm{M}) 10 \mathrm{~min}$ before completing the preincubation period. Histamine or epinephrine were added for varying time intervals and the water soluble cellular products were extracted and separated by ion exchange chromatography on Dowex-1 resin columns as previously described using $100 \mathrm{mM}$ increments of ammonium formate (8). Inositol monophosphate was eluted with $10 \mathrm{mM}$ formic acid/100 $\mathrm{mM}$ ammonium formate $/ 5 \mathrm{mM}$ disodium tetraborate, inositol bisphosphate was eluted with $20 \mathrm{mM}$ formic ac$\mathrm{id} / 200 \mathrm{mM}$ ammonium formate $/ 5 \mathrm{mM}$ disodium tetraborate, and inositol trisphosphate (IP3) was eluted with $30 \mathrm{mM}$ formic acid/300 mM ammonium formate $/ 5 \mathrm{mM}$ disodium tetraborate. The fraction containing IP 3 consists of a mixture containing the $1,4,5$ and the $1,3,4$ isomers.

\section{RESULTS}

As shown in Fig. 2, epinephrine, the catecholamine used in these studies, dose-dependently stimulated the production of cyclic 3',5'-adenosine monophosphate (cAMP) in nontransfected

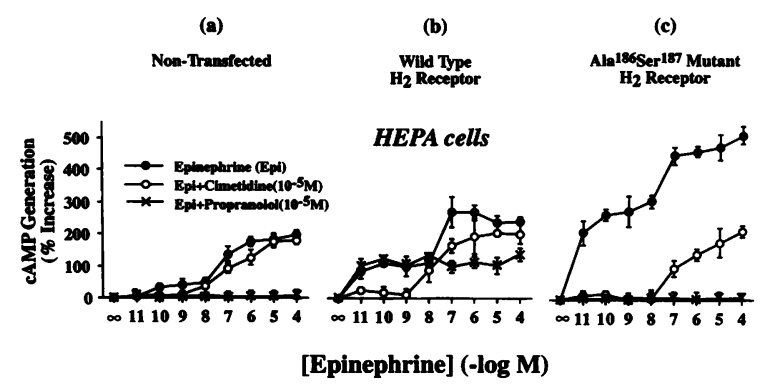

FIG. 2. Effect of epinephrine on cAMP generation in transfected Hepa cells

(a) Epinephrine dose-dependently stimulated cAMP generation in nontransfected Hepa cells (EC50 = $5 \times 10^{-8} \mathrm{M}$, maximum response $=278 \pm 44 \%$ above control, means \pm SEM, $n=4)$. This effect was inhibited by propranolol $\left(10^{-5} \mathrm{M}\right)$ but not by cimetidine $\left(10^{-5} \mathrm{M}\right)$. In Hepa cells transfected with the wild-type $\mathrm{H} 2$ receptor (b), epinephrine stimulated cAMP generation in a biphasic fashion. The stimulatory effect of low-dose epinephrine $\left(10^{-11}\right.$ to $10^{-9} \mathrm{M}$ ) on cAMP formation was inhibited by cimetidine and not by propranolol, while the effect observed with higher concentrations of epinephrine $\left(10^{-8}\right.$ to $\left.10^{-4} \mathrm{M}\right)$ was inhibited by propranolol and not by cimetidine. (c) The stimulatory action of epinephrine on cAMP generation was markedly enhanced in Hepa cells transfected with the Ala ${ }^{186}$. $\mathrm{Ser}^{187}$ mutant H2-histamine receptor (maximum response $=280 \pm 15 \%$ above control). The response to low dose epinephrine $\left(10^{-11}\right.$ to $\left.10^{-9} \mathrm{M}\right)$ was inhibited with both cimetidine and propranolol while the response to high epinephrine concentrations $\left(10^{-8}\right.$ to $\left.10^{-4} \mathrm{M}\right)$ remained sensitive only to propranolol. Consistent with our previous studies, histamine stimulated cAMP generation in Hepa cells expressing both wild-type and mutant $\mathrm{H} 2$ histamine receptors (data not shown).

Hepa cells. These stimulatory effects, obtained at relatively high concentrations of epinephrine (ED50 $\left.=10^{-7} \mathrm{M}\right)$, could be inhibited by propranolol but not cimetidine. Thus, there appears to be a classical $\beta$-adrenergic receptor on Hepa cells. After transfection with the wild type H2histamine receptor gene, the Hepa cells demonstrated a biphasic response to epinephrine. The later phase of the response presumably represented the endogenous $\beta$-adrenergic receptors and mirrored the effect observed in nontransfected Hepa cells. In contrast, the initial phase of the cAMP response to catecholamine had a much lower ED50 $\left(<10^{-11} \mathrm{M}\right)$ and was inhibited with cimetidine but not propranolol. These data indicate that catecholamines are capable of having a minimal action at the standard $\mathrm{H} 2$ receptor, perhaps on the basis of the existing similarity in the structure of the binding sites of H2-histamine 


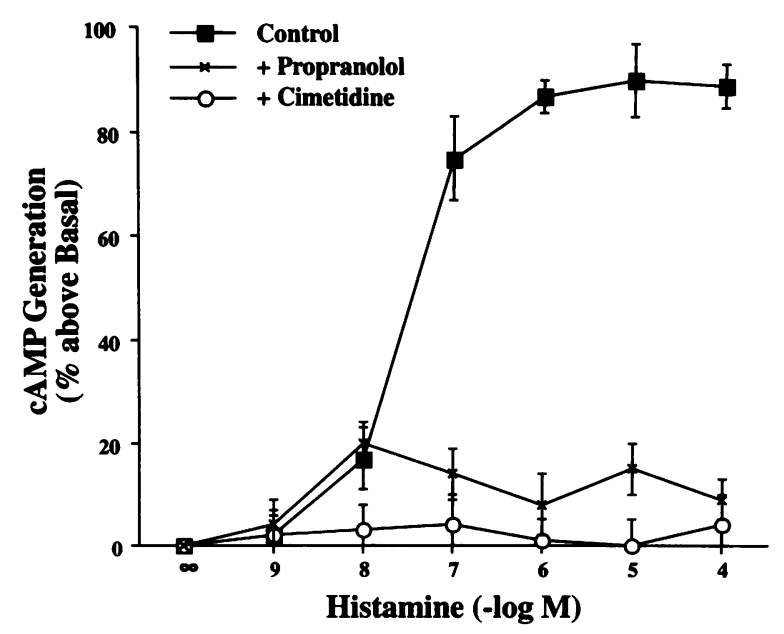

FIG. 3. Effect of histamine on cAMP generation in transfected Hepa cells

Although histamine had no effect on nontransfected Hepa cells (data not shown), it stimulated cAMP formation in cells transfected with the $\mathrm{Ala}^{186}-\mathrm{Ser}^{187}$ mutant $\mathrm{H} 2$-histamine receptor $\left(\mathrm{ED} 50=3 \times 10^{-8}\right.$ $M$ ) in a fashion that could be inhibited by cimetidine $\left(10^{-5} \mathrm{M}\right)$ and propranolol $\left(10^{-5} \mathrm{M}\right)$. Data are represented as means \pm SEM, $\mathrm{n}=4$.

and $\beta$-adrenergic receptors. Upon transfection with the $\mathrm{Ala}^{186}-\mathrm{Ser}^{187}$ mutant H2-histamine receptor, the Hepa cells demonstrated, once again, a biphasic response. However, in this instance, the initial phase was greatly exaggerated and, in contrast to the effect obtained with the wild-type H2-histamine receptor, inhibited with either cimetidine or propranolol. As depicted in Fig. 3, histamine dose-dependently stimulated cAMP formation in Hepa cells transfected with the $\mathrm{Ala}^{186}$-Ser ${ }^{187}$ mutant $\mathrm{H} 2$-histamine receptor with an ED50 $\left(3 \times 10^{-8} \mathrm{M}\right)$ which is similar to that obtained in Hepa cells transfected with the wildtype receptor (data not shown). It is of note that the stimulatory effect of histamine on Hepa cells transfected with the mutant $\mathrm{H} 2$ receptor was inhibited with both cimetidine and propranolol, whereas the effect of this secretagogue on the wildtype H2-receptor was inhibited only by cimetidine (data not shown). These data demonstrate that the mutant H2-histamine receptor had the bifunctional properties of $\mathrm{H} 2$-histamine and $\beta$-adrenergic receptors.

We conducted additional studies to characterize the bifunctional nature of the $\mathrm{Ala}^{186}$. Ser $^{187}$ mutant H2-histamine receptor using selective agonists and antagonists. As shown in Fig. 4, the cAMP response to epinephrine at a dose of $10^{-9} \mathrm{M}$, which is below the threshold of

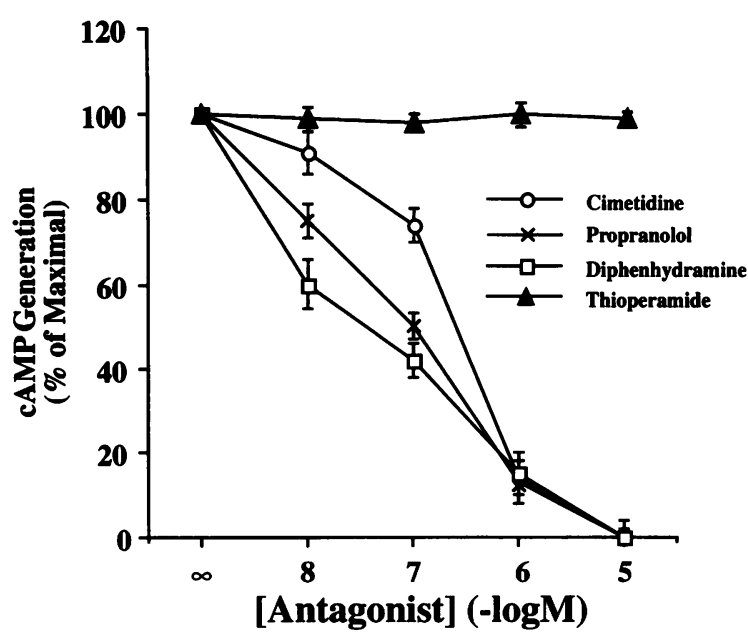

FIG. 4. Effect of propranolol, cimetidine, diphenhydramine and thioperamide on epinephrine stimulated cAMP generation in Hepa cells transfected with the mutant Ala ${ }^{186}-$ Ser $^{187}$ H2histamine receptor

Propranolol, cimetidine, and diphenhydramine dosedependently inhibited cAMP generation stimulated by epinephrine with IC50 values of $1 \pm 0.3 \times 10^{-7} \mathrm{M}, 5 \pm 0.45 \times 10^{-7} \mathrm{M}$, and $5 \pm$ $1.2 \times 10^{-8} \mathrm{M}$, respectively. Thioperamide did not alter epinephrine stimulated cAMP formation in transfected cells. Data are represented as means \pm $\mathrm{SEM}, \mathrm{n}=4$.

the endogenous Hepa cell $\beta$-adrenergic receptor, could be inhibited with propranolol, cimetidine, and diphenhydramine, an H1-histamine receptor antagonist. Similarly, when the stimulatory ligand used was histamine, the same inhibitory pattern was observed with the H2-histamine and $\beta$-adrenergic receptor antagonists. The H3-histamine receptor antagonist thioperamide did not inhibit either epinephrine or histamine stimulated CAMP formation. Thus, the mutant receptor responded to both adrenergic and histaminergic stimuli and was inhibited by selective antagonists for either class of ligands. It is of considerable interest that the $\mathrm{Ala}^{186}-\mathrm{Ser}^{187} \mathrm{mu}$ tant confers $\mathrm{Hl}$-histamine receptor properties to the $\mathrm{H} 2$ receptor. This effect was predicted by our previous studies demonstrating that $\mathrm{Asp}^{186}$ of the $\mathrm{H} 2$-histamine receptor defines $\mathrm{H} 2$ selectivity but is not an essential element in histamine binding (2).

One feature that differentiates $\mathrm{H} 2$-histamine from $\beta$-adrenergic receptors is that while both receptors are capable of generating a cellular cAMP response, only the former has been shown simultaneously to induce significant turnover of 


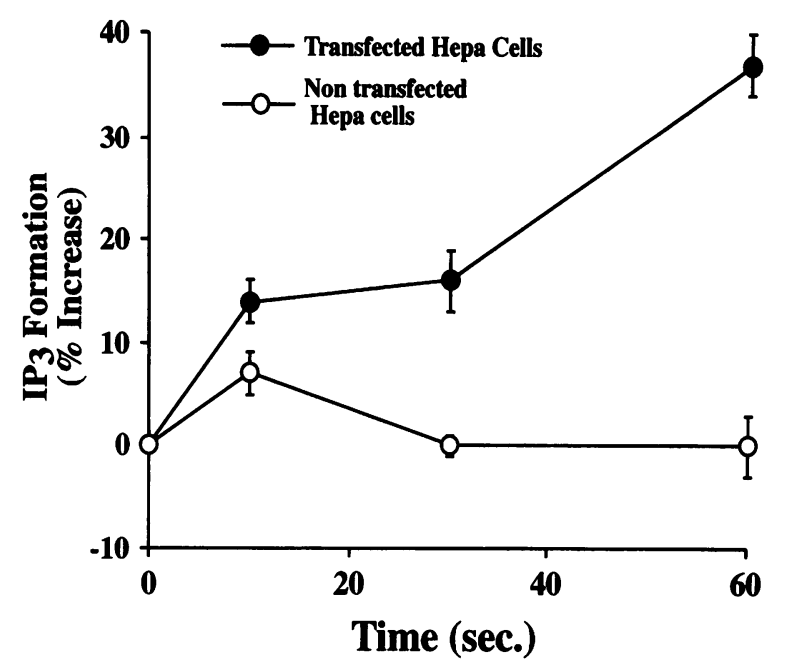

FIG. 5. Effect of epinephrine on inositol trisphosphate (IP3) generation in Hepa cells transfected with the wild-type and Ala ${ }^{186}$ Ser $^{187}$ mutant H2-histamine receptor

Epinephrine at a maximal concentration of $10^{-5} \mathrm{M}$ induced a time-dependent increase in IP3 generation in Hepa cells expressing the mutant $\mathrm{Ala}^{186}-\mathrm{Ser}^{187}$ $\mathrm{H} 2$-histamine receptor but had no such effect on nontransfected Hepa cells. Data are represented as means \pm SEM, $n=4$.

membrane inositol phospholipids and mobilize intracellular calcium (9). Accordingly, to verify that the catecholamine response that we were observing in the Hepa cells transfected with the $\mathrm{Ala}^{186}$-Ser ${ }^{187}$ mutant $\mathrm{H} 2$-histamine receptor was a result of action at the mutant histamine receptor and not the endogenous catecholamine receptor, we examined the effect of epinephrine on membrane inositol phospholipid turnover as measured by the production of IP3. As shown in Fig. 5, epinephrine $\left(10^{-5} \mathrm{M}\right)$ induced IP3 generation in Hepa cells transfected with the $\mathrm{Ala}^{186}$. $\mathrm{Ser}^{187}$ mutant H2-histamine receptor. Only a minimal IP3 response was noted at the 10 -sec time point in nontransfected Hepa cells. These data confirm that, despite the presence of an endogenous $\beta$-adrenergic receptor, there were selective responses of transfected Hepa cells to epinephrine that could be mediated only via action at a bifunctional histamine receptor.

For further confirmation of the bifunctional nature of the $\mathrm{Ala}^{186}$-Ser ${ }^{187}$ mutant $\mathrm{H} 2$-histamine receptor, we transfected both the wild-type and mutant $\mathrm{H} 2$-histamine receptors into a second cell line, the L cell. As depicted in Fig. 6, unlike the Hepa cells, nontransfected L cells demonstrated no cAMP response to epinephrine, indicating

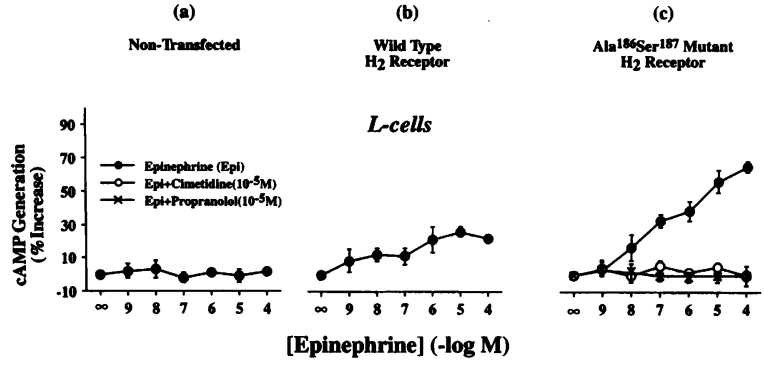

FIG. 6. Effect of epinephrine on transfected $L$ cells

Epinephrine produced no increase in cAMP levels in nontransfected L cells (a) and only a small increase at high concentrations in L cells transfected with the wild-type H2-histamine receptor (b). The latter effect was abolished with cimetidine $\left(10^{-5} \mathrm{M}\right)$ but not with propranolol $\left(10^{-5} \mathrm{M}\right)$. However, epinephrine induced a dose-dependent rise in cAMP generation in cells transfected with the mutant $\mathrm{Ala}^{186}-\mathrm{Ser}^{187}$ $\mathrm{H} 2$-histamine receptor (c). This stimulatory effect was inhibited by both cimetidine and propranolol. Histamine increased cAMP levels in L cells transfected with the wild-type H2-histamine and the $\mathrm{Ala}^{186}-\mathrm{Ser}^{187}$ mutant receptors, but did not alter cAMP levels in nontransfected cells (data not shown). Data are represented as means \pm SEM, $\mathrm{n}=4$.

that they do not express endogenous adrenergic receptors. In very high concentrations, epinephrine demonstrated some ability to induce cAMP generation via action at the wild-type $\mathrm{H} 2$ receptor, although this response was inhibited only with cimetidine and not with propranolol. However, a much more characteristic cAMP response to epinephrine was noted in L cells transfected with the $\mathrm{Ala}^{186}$-Ser ${ }^{187}$ mutant $\mathrm{H} 2$ receptor, and this response was inhibited completely with both propranolol and cimetidine. Histamine also induced a dose-dependent rise in cAMP formation in $\mathrm{L}$ cells transfected with the $\mathrm{Ala}^{186}-\mathrm{Ser}^{187}$ mutant $\mathrm{H} 2$ receptor (Fig. 7) and, as with epinephrine, this effect was inhibited with both propranolol and cimetidine. The maximal stimulatory effect of histamine was less than that seen with the wild-type $\mathrm{H} 2$ receptor, but the ED50 was similar in both instances. Nontransfected L cells demonstrated no response to histamine. These findings confirm the bifunctional nature of the receptor that transduces the responses activated by epinephrine and histamine. The relatively broad configuration of the dose response curves shown in Figs. 6 and 7 may result from the actions of epinephrine and histamine at a bifunctional receptor as opposed to a single receptor subtype. 


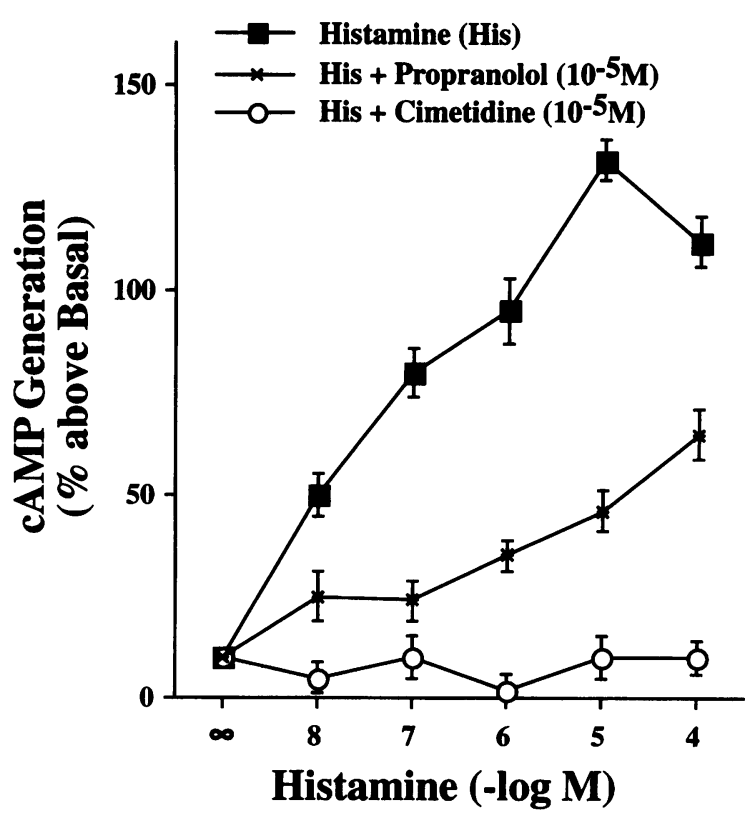

FIG. 7. Effect of histamine on cAMP generation in transfected $L$ cells

Histamine had no effect on nontransfected L cells, but stimulated cAMP formation in L cells transfected with the wild-type $\mathrm{H} 2$ receptor in a fashion that could be inhibited by cimetidine (data not shown). Histamine also stimulated cAMP formation in L cells transfected with the Ala ${ }^{186}-\mathrm{Ser}^{187}$ mutant $\mathrm{H} 2$ receptor in a dose-dependent fashion (ED50 = $5 \times 10^{-8}$ $M)$. The response to histamine was inhibited by both propranolol and cimetidine. Data are represented as means \pm SEM, $\mathrm{n}=4$.

\section{DISCUSSION}

We have demonstrated that two amino acid substitutions are sufficient to convert the $\mathrm{H} 2$-histamine receptor into a bifunctional one that has characteristics of both the histamine and adrenergic receptors. Our studies suggest that the ligand specific binding properties of a receptor are determined by a surprisingly limited number of key amino acids in its molecular structure. Although there is broad structural similarity among seven transmembrane $G$ protein-linked receptors, there is relatively low amino acid homology between families of receptors for different classes of agonists. Despite the relatively modest overall structural homology between the H2-histamine and $\beta 2$-adrenergic receptors, two simple amino acid substitutions are sufficient to convert the former receptor into one that has the ligand recognition characteristics of both. Seemingly minor amino acid changes have been reported previously to have profound effects on the pharmacology of $G$ protein-linked seven transmembrane receptors. For example, the alteration of a single amino acid has been shown to account for the pharmacological differences between the rat and human 5-hydroxytryptamine $1 \mathrm{~B}$ receptors $(10,11)$ and the canine and human cholecystokinin-B/gastrin receptors (12). Similarly, a point mutation in the $\alpha 2$-adrenergic or 5-hydroxytryptamine $1 \mathrm{~A}$ receptors changes their affinity for $\beta$-adrenergic receptor antagonists $(13,14)$. In other studies the receptors for the tachykinins substance $\mathrm{P}$ ( $\mathrm{NKl}$ receptor) and neurokinin $\mathrm{B}$ (NK3 receptor) have been shown to exhibit alterations in receptor binding affinity to nonpeptide antagonists as a result of changes in only one or two of its amino acid residues (15-17).

Our experiments provide the first demonstration that such minor amino acid changes can result in changes in ligand specificity so major that they can cross the gap between entire families of receptors that have only modest structural homology. These findings have important implications in the design of pharmacological agents that are directed at physiological receptors. It is possible, for example, that so-called specific receptor antagonists or agonists may have crossover effects on other groups of receptors that would not be predicted on the basis of overall structural homology. Moreover, it may be possible to utilize unique agonists or antagonists for targeting ligand delivery to artificially constructed mutant receptors that are transfected into various tissues in the body.

\section{ACKNOWLEDGMENTS}

This work was supported by National Institutes of Health (NIH) Grants RO1DK34306 and RO1DK47434, and funds from the University of Michigan Gastrointestinal Peptide Research Center (NIH Grant P30DK34933). Dr. Gantz is a recipient of a Veterans Administration Research Associate Award. We thank Drs. J. Dixon and M. Uhler for their helpful comments on this manuscript.

\section{REFERENCES}

1. Gantz I, Schaffer M, DelValle J, et al. (1991) Cloning of the $\mathrm{H}_{2}$ histamine receptor. Proc. Natl. Acad. Sci. U.S.A. 88: 429-433.

2. Gantz I, DelValle J, Wang L-D, et al. (1992) Molecular basis for the interaction of hista- 
mine with the histamine $\mathrm{H}_{2}$ receptor. J. Biol. Chem. 267: 20840-20843.

3. Strader CD, Sigal IS, Register RB, Candelore MR, Rands E, Dixon RAF. (1987) Identification of residues required for ligand binding to the beta-adrenergic receptor. Proc. Natl. Acad. Sci. U.S.A. 84: 4384-4388.

4. Strader CD, Candelore MR, Hill WS, Sigal IS, Dixon RAF. (1989) Identification of two serine residues involved in agonist activation of the $\beta$-adrenergic receptor. J. Biol. Chem. 264: 13572-13578.

5. Kunkel TA, Roberts JD, Zabour RA. (1987) Rapid and efficient site-specific mutagenesis without phenotypic selection. Methods Enzymol. 154: 367-382.

6. Brown NA, Steofko RE, Uhler MD. (1990) Induction of alkaline phosphatase in mouse $\mathrm{L}$ cells by overexpression of the catalytic subunit of cAMP-dependent protein kinase. $J$. Biol. Chem. 265: 13181-13189.

7. Chen CA, Okayama H. (1988) Calcium phosphate-mediated gene transfer: A highly efficient transfection system for stably transforming cells with plasmid DNA. Biotechniques 6: 632-638.

8. Wreggett KA, Irvine RF. (1987) A rapid separation method for inositol phosphates and their isomers. Biochem. J. 245: 655-660.

9. DelValle J, Wang L-D, Gantz I, Schaffer M, Yamada T. (1992) Characterization of $\mathrm{H}_{2}$ histamine receptor: Linkage to both adenylate cyclase and $\left[\mathrm{Ca}^{2+}\right]_{\mathrm{i}}$ signaling systems. Am. J. Physiol. 263: G967-G972.

10. Oksenberg D, Marsters SA, O'Dowd BF, et al. (1992) A single amino-acid difference confers major pharmacological variation between human and rodent $5-\mathrm{HT} 1 \mathrm{~B}$ receptors. Nature 360: 161-163.

Contributed by T. Yamada on January 12, 1995.
11. Parker EM, Grisel DA, Iben LG, Shapiro RA. (1993) A single amino acid difference accounts for the pharmacological distinctions between the rat and human 5-hydroxytryptaminelB receptors. J. Neurochem. 60: 380-383.

12. Beinborn M, Lee $\mathrm{Y}-\mathrm{M}$, McBride EW, Quinn SM, Kopin AS. (1993) A single amino acid of the cholecystokinin-B/gastrin receptor determines specificity for non-peptide antagonists. Nature 362: 348-350.

13. Suryanarayana S, Daunt DA, Von Zastrow M, Kobilka BK. (1991) A point mutation in the seventh hydrophobic domain of the alpha 2 adrenergic receptor increases its affinity for a family of beta receptor antagonists. J. Biol. Chem. 266: 15488-15492.

14. Guan X-M, Peroutka SJ, Kobilka BK. (1992) Identification of a single amino acid residue responsible for the binding of a class of betaadrenergic receptor antagonists to 5-hydroxytryptaminelA receptors. Mol. Pharm. 41: 695-698.

15. Fong TM, Yu H, Strader CD. (1992) Molecular basis for the species selectivity of the neurokinin-1 receptor antagonists CP-96, 345 and RP67580. J. Biol. Chem. 267: 2566825671.

16. Sachais BS, Snider RM, Low JA, Krause JE. (1993) Molecular basis for the species selectivity of the substance P antagonist CP-96, 345. J. Biol. Chem. 268: 2319-2323.

17. Gether U, Johansen TE, Snider RM, Lowe III JA, Nakanishi S, Schwartz TW. (1993) Different binding epitopes on the NK1 receptor for substance $P$ and non-peptide antagonist. Nature 362: 345-348. 